\title{
Waste Management Strategies for Proper Household Hygiene in Orumba-South Local Government Area of Anambra-State, Nigeria
}

\author{
Uju E. Nnubia
}

\author{
Department of Home Economics/Home Management and Tourism \\ College of Applied Food Sciences and Tourism \\ Michael Okpara University of Agriculture, Umudike, Abia-State, Nigeria
}

Doi:10.5901/ajis.2014.v3n7p115

\begin{abstract}
This study was designed to investigate waste management strategies for proper household hygiene in Orumba-South Local Government Area of Anambra- State, Nigeria. Three research questions guided the study. Questionnaire was used to collect relevant data from a random sample of 200 households in Orumba-South Local Government Area. Mean was used to analyse the data collected. The findings revealed among others that most households in Orumba-South Local Government Area dispose their waste by indiscriminate dumping on roadside, sumps, streams; using discarded containers as waste bins. It also revealed that indiscriminate dumping of wastes among others cause air, water and land pollution, forming breeding sites for vector agents, transmission of communicable diseases and parasitic infections. Finally, it was also revealed among other strategies that enough public waste disposal facilities should be provided; there should be provision of separate disposal facilities for different forms of wastes accumulated by various households instead of dumping all the wastes in one facility. Based on the findings, five recommendations were given on how to improve on waste management practices.
\end{abstract}

Keywords: Waste, waste management, household and hygiene

\section{Introduction}

Waste management is one of the major challenges facing households in Nigeria. This challenge has occupied the attention of the Federal, State, and Local Government Authorities for many years. Advocates of environmental protection have called for appropriate legislation and regulation to control and protect Nigeria environment from further deterioration particularly in connection with the management of wastes in cities and urban areas (Olajoyegbe, 1995).

Wastes are generated everyday in individual household due to activities that go on there. According to Asare, Quartey and Amu (2008), waste is unwanted, useless materials, junk trash and no longer needed materials that result from domestic or household activities or consumption. Thus, waste can either be in liquid or solid forms. Liquid wastes include all dirty water from bathroom, toilet (water closet), kitchen and sometimes rain water collected by gutters. While solid wastes include all other rubbish household members accumulate such as waste foods, pieces of papers, broken bottles, ashes from fire, cloths, cellophane bags, empty cans and tins, broken plates etc.

These wastes need to be properly disposed to ensure good health of household members. The quality of health of household members depends to a large extent on the hygienic condition of the home. Hygiene according to Hornby (2005), is the practice of keeping oneself and his/her living and working areas clean in order to prevent illness and diseases. Therefore, any activity one engages in to live healthy life, including waste disposal, are gearing towards provision of hygienic environment for household members. Unhygienic disposal of wastes accumulated by household is a great threat to the life of its members. This might result in food and water borne diseases. Some pollutants according to Palamulleni (2001) get into the human system because of unhygienic practices such as not covering of food, improper disposal of wastes, eating unwashed food, not washing hands and drinking untreated water. Therefore, proper waste management plays a vital role in the provision of safe foods and hygienic conditions for the household especially at this period Ebola Virus Disease (EVD) has found its way into the country. All possible hygienic practices should come on hand in controlling its further spread.

Waste management is the generation, prevention, monitoring, treatment, handling, re-use, and residual disposition of wastes. It relates to materials produced by human activities and the process generally undertaken to reduce their effects on health, environment or aesthetic (Grandy, 1994). When wastes are properly managed, the incidence of food and water borne diseases such as cholera, typhoid fever, dysentery, diarrhea and food poisoning will decline (Food and 
Agricultural Organization FAO: 2002). This gesture (i.e. proper management of wastes) however, has both health and economic implications for the households. For instance, the economic development of household depends to a large extent on the health of its members which invariably depends on the hygienic conditions of the home. If a home is to provide suitable environment for the overall development of its member, adequate sanitation must be maintained.

It is disheartening that poor waste management practices are still common in households mostly in urban cities in Nigeria as noted by Aina (1992). This might be as a result of population increase, urbanization and so on. Cities like Onitsha, Lagos have various stinking refuse heaps and dump sites as well as stinking gutters (Noibi, 1992). Nevertheless, proper waste management is extremely important in the household hygiene and in control of both water and food borne diseases

Orumba-South is one of the local government areas in Anambra-State of Nigeria. It is a semi-urban area that is witnessing a sporadic growth in both population and infrastructural development. The population of the areas has doubled recently as a result of the existence of the federal tertiary institution and a number of commercial banks. Most of the liquid and solid wastes generated by various households are indiscriminately disposed, thereby littering the streets and major roads, thus, living the environment in a sorry state.

This paper therefore, investigated the waste disposal methods, implications of the methods used and finally, waste management strategies for proper household hygiene in Orumba-South Local Government Area in Anambra-State of Nigeria.

\section{Purpose of the Study}

The major purpose of the study was to investigate waste management strategies for proper household hygiene in Orumba-South L G Area. Specifically, the study investigated:

1. Methods of waste disposal by households in Orumba-South L. G Area.

2. Implications of the methods used.

3. Waste management strategies for proper household hygiene.

\section{Research Questions}

1. What are the methods adopted by households in Orumba-South L. G Area for wastes disposal?

2. What are the implications of the methods adopted?

3. What are the waste management strategies for proper household hygiene?

\section{Methodology}

The study was basically a survey research, designed to determine the methods households in Orumba-South L G Areas adopt for disposal of wastes, the implications of the methods adopted and finally, the waste management strategies for proper household hygiene.

The population for the study was made up of all the households on Orumba-South L. G Area. Orumba-South L G Area with an estimated population of 1,845,481 by the 2006 Nigerian population census has continued to increase due to the influx of migrants from other parts of the country as a result of the presence of the federal tertiary institution and commercial banks in the local government area. The area of the study was zoned into fifteen according to the fifteen towns that make up the local government.

Ten zones were purposively selected out of the fifteen zones. A total of 20 households were selected from each zone making it a total of 200 households. One person (home maker) was selected in each household to participate in the study.

Questionnaire was the instrument used for data collection. This was developed based on the literature reviewed and research questions. Five point Likert rating scale of 'Strongly Agree' to 'Strongly Disagree' was used for the data collection. The instrument was validated by three Home Economics lecturers from Michael Okpara University of Agriculture, Umudike Abia-State and the reliability was determined using Cronbach's Alpha procedure. A reliability Coefficient of 0.80 was obtained.

Two hundred copies of the questionnaire were administered by hand to the respondents with the help of two research assistants. Two weeks period was given to enable the respondents fill the copies. $100 \%$ return rate was achieved. 
The data gathered was analyzed using mean of 3.05 or above as 'Agree' while any response with mean score below 3.05 was regarded as 'Disagree'

\section{Research Findings}

The tables below show the analysis of data related to each question.

Table 1: Methods of Waste Disposal by Households in Orumba-South L. G. Area

\begin{tabular}{|c|l|c|c|}
\hline S/N & Items & Mean & Remark \\
\hline 1 & Using family farm land & 4.00 & Agree \\
\hline 2 & Using road side as dump site & 4.04 & Agree \\
\hline 3 & Using any discarded container and bags as waste bins & 3.93 & Agree \\
\hline 4 & Using water sumps as dumping site & 3.93 & Agree \\
\hline 5 & Pouring dirty water from the kitchen at the back of the yard & 3.93 & Agree \\
\hline 6 & Incineration of wastes in front or back of their homes & 3.77 & Agree \\
\hline 7 & Allowing water from the bathroom to flow outside the family compound & 4.13 & Agree \\
\hline 8 & Dumping waste into the village streams, rivers and valleys around & 3.36 & Agree \\
\hline 9 & Using authorized locations for dumping & 2.25 & Disagree \\
\hline 10 & Recycling of wastes into by-product/raw materials & 2.98 & Disagree \\
\hline
\end{tabular}

Table 1 above indicated that the mean rating of the respondents on methods of waste disposal by households in Orumba-South L. G Area were higher than cut-off point of 3.05. Out of the ten items raised, only two items (items 9 and 10) scored less than the cut-off point. This implies that the other eight items were methods households use in the disposal of their waste in Orumba-South L. G Area.

Table 2: Implications of Methods of Waste Disposal by Households in Orumba-South L.G.Area.

\begin{tabular}{|c|l|c|c|}
\hline S/N & Items & Mean & Remark \\
\hline 1 & Major roads are breeding site for vector agents & 4.02 & Agree \\
\hline 2 & Dumped wastes on corners of the roads causes air pollution & 3.60 & Agree \\
\hline 3 & Indiscriminate dumping of waste causes land pollution & 4.00 & Agree \\
\hline 4 & Water channels are blocked & 4.77 & Agree \\
\hline 5 & There is transmission of communicable diseases & 3.42 & Agree \\
\hline 6 & There is transmission of parasitic infections & 3.77 & Agree \\
\hline 7 & During raining seasons roads are flooded as a result of water channels blockage. & 4.00 & Agree \\
\hline 8 & There are road accidents as a result of flood effects on roads. & 3.86 & Agree \\
\hline 9 & Pedestrians atimes get stucked in water channels & 3.42 & Agree \\
\hline 10 & A lot of potholes on the road as a result of erosion & 3.42 & Agree \\
\hline 11 & Most streets are no more motorable & 4.66 & Agree \\
\hline
\end{tabular}

Table 2 above shows that all the respondents agree to the eleven items raised as implications of wastes are disposed in Orumba South L G Area. 
Table 3: Management Strategies for Proper Household Hygiene in Orumba-South L. G Area

\begin{tabular}{|c|l|c|c|}
\hline S/N & Items & Mean & Remark \\
\hline 1 & Provision of proper public disposal facilities & 4.01 & Agree \\
\hline 2 & Emptying waste disposal facilities always & 4.32 & Agree \\
\hline 3 & Removing waste bins from the kitchen before going to bed & 3.81 & Agree \\
\hline 4 & Wash up all the dirty utensils on before going to bed & 3.65 & Agree \\
\hline 5 & Provision of separate bins for collection of different forms of wastes & 4.00 & Agree \\
\hline 6 & Avoid using one disposable facility for all forms of waste from the household & 4.02 & Agree \\
\hline 7 & Always burn dry wastes & 3.76 & Agree \\
\hline 8 & Wastes like broken bottles, cups, and tins should be buried & 3.77 & Agree \\
\hline 9 & Home makers should keep proper monitoring of hygienic condition of the household & 3.46 & Agree \\
\hline 10 & Used sachets and empty bottled water cans should be properly disposed & 4.02 & Agree \\
\hline 11 & Provision of waste bins with good lids. & 4.20 & Agree \\
\hline
\end{tabular}

All the items above scored 3.05 and above showing that the respondents accepted them as waste management strategies for proper household hygiene.

\section{Discussion of the Findings}

The major finding in table 1 shows that households in Orumba-South L G Area do not have any authorized area for dumping of waste. This is the major reason why households members dump wastes along the roads and sumps in the area studied. Table 1 also revealed that waste disposal methods of households in Orumba-South L G Area are inadequate. They allow water from toilets, kitchens and bathrooms to flow outside their compound, they dump wastes into their village streams, rivers, sumps, using discarded containers for dumping of wastes instead of using proper disposal facilities with good lids, using farm lands as dumping sites. These practices are not in line with Federal Government of Nigeria (1998) which stressed strategies for sustainable management of solid waste in the country through source reduction, recycling, incineration and land filling which could be combined and designed to complement each other as well as to be flexible enough to handle future changes in the local waste management system.

Table 2 revealed eleven implications of the methods of waste disposal in Orumba-South L G Area to include transmission of communicable diseases and parasitic infections, blockage of water channels and sumps, potholes at the middle of major streets, some wastes decompose and attract germs and viruses, old containers and tomatoes tins, broken bottles collect water inside forming good breeding places for mosquitoes and can even cause accidents like cuts, tumbling of cars, etc. These implications are in line with Asare and Kwafoa (2011) who observed that variety of environmental health hazard is associated with improper storage of waste. For example, flies and mosquitoes breeding are encouraged by uncovered waste container and these flies may play a role in the mechanical transmission of faeces and consequently of faeca-oral-diseases such as amoebic dysentery, cholera, Salmonellas, enteric fever and typhoid fever. In line with these implications Alo (2006), stated that liquid and solid wastes that form the bulk of household wastes in Nigeria pose serious problems in the environment besides unsightly appearances and stinky, household wastes promote vector breeding and encourage transmission of diarrhea and other parasitic infection The indiscriminate dumping of waste makes the environment very dirty and smelly causing water, air and land pollution as noted by Anyakoha (1994) who said that household waste can decay, thus producing an unpleasant smell, it can also provide food for rats and breeding places for flies thereby constituting danger to health. It is also in line with Asare, Quartey and Amu (2008), who noted that improper disposal of both liquid and solid wastes, contributes to the pollution of the environment. Stressing further, they maintained that indiscriminate waste disposal practices cause diseases like cholera, typhoid, schistosomaisis and elephantiasis which are life threatening.

Table 3 identified waste management strategies for proper household hygiene to include: provision of proper public disposal facilities, mapping out an authorized sight for dumping of waste, emptying waste disposal facilities always, avoiding using one disposable facility for all kinds of wastes, provision/use of waste bins with good lids and so on. These are in line with the findings of Saka (1995) who noted that ideally households are supposed to have refuse containers with good lids to store her wastes, and regularly dispose the wastes at the government approved authorized sites. This is due to the fact that government waste management starts where individual waste management responsibilities stop. It is the responsibility of government to collect wastes at regular intervals and have them dispose to the final dump site. 


\section{Recommendations}

Based on the findings of the study, the researcher recommends that;

1. Local government authorities should step up public enlighten campaigns on radio, churches, and village meetings to get people educated on the effects of improper waste management on their health.

2. Functional waste management education should be organized for women preferably at informal gathering setting such as antenatal and postnatal clinics and meetings of their various associations.

3. There should be strict enforcement of legislation of default of sanitation laws.

4. Local government authority should provide enough public disposal facilities at adequate points taking into consideration the density of settlements.

5. Waste management skill should be included in school curriculum and be thought at all levels of education in Nigeria.

\section{Conclusion}

From the result of the investigation, it was established that methods of waste disposal in Orumba-South L G Area of Anambra State in Nigeria is inadequate. Mostly is as a result of lack of public authorized site for dumping of waste in the whole area studied.

Such indiscriminate disposal of waste forms breeding places for disease carrying vectors and pests. Due to the organic nature of some of these wastes upon disposal, the decompose and attract germs of all kinds, there is also blockage of water channel, sumps and so on causing the whole environment to be unsightly.

Finally, it was revealed that provision of disposal facilities with good lids and provision of good site by government are some of the waste management strategies for proper household hygiene.

\section{References}

Aina, F (1992) Nigeria's Growing Romance with Dump Site. Sunday Concord Newspaper, June, 26, 13-15

Anyakoha, E. U and Eluwa, M. A (1994), Home Management for Schools and Colleges. Onitsha, Africana First, Publishers Ltd

Alo, R (2006) Prognosis of Environmental Management in Lagos State in this our Earth. Proceedings of the Advocacy Workshop for Environmental Agencies in Lagos State coordinated by the New Era Foundations.

Asare and Kwafoa (2011) Understanding Management in Living. Ghana, Kwadwoani Publishing

Asare, Quartey and Amu (2008) Housing the Family. Ghana, Asquart Publishers

Food and Agricultural Organization of the United Nations (2002) Improving Efficiency and Transparancy in Food Services. Rome

Federal Government of Nigeria (1998) Federal Government Blue Print on Municipal Solid Waste Management in Nigeria in Anozie, G. O. Research Issues in Home Economics, Nsukka, HERAN

Grandy, M (1994) Recycling and the politics of urban Waste. Earthscan

Hornby, A. S (2005) Oxford Advanced Learner's Dictionary of Current English (7 ${ }^{\text {thed }}$ ) New York, Oxford University Press

Noibi, Y (1992) Pollution: An Environment Challenge to Nigeria, National Concord June 5, p. 14.

Olajoyegbe (1995) Household Waste Management, A must for Community Health and Sustained development. Proceeding of a Seminar on Strategies on Household Waste Management Organized by Goethe Institute, Lagos

Palamulani, L. G (2001) Effect of Sanitation facilities of Domestic Solid waste Disposal and Hygiene practices on Water quality in Malawi Urban Poor Areas, Waternet Symposium Cape Town 30- 31 October, 283-290.

Saka, G.O (1995) Thy Waste be Dumped, Strategies and Household Management. Lagos, Goethe Institute 